\section{Refugees: Requiring Urgent Reforms}

\author{
by Sergio Marchi, MP, York West \\ Opposition Critic for Immigration and Multiculturalism
}

IN THE PAST TWO YEARS Canada's relation to refugees has been under extensive review. Refugee determination has become one of the key concerns of our present day immigration policy. Although much public attention has been given to this issue, govermment policy action to rectify the unfair and unjust system has lagged behind.

It is time that we, as a nation concerned with a fair and just democratic system, commence to address this issue expediently and in a responsible progressive manner.

The most obvious and damaging policy component is that the government is prepared to limit access to the refugee determination process on the grounds of the claimant's country of last sojourn. The vast majority of refugees must escape their country into a secondary country before coming into Canada, since persecution cuts off direct access to Canada.

In addition, the government proposes a terribly weak appeal procedure to Federal Court, is silent on the right of legal counsel from the initial stages of the process, recommends legisla-

\section{Visas Versus Refugees}

\section{by Dan Heap, MP, Spadina NDP Critic, Immigration}

CANADA HAS BEEN quick to require visas of people coming from right-wing dictatorships to claim refugee status here, but slow to stop the notorious abuse by thousands of "Jehovah's Wintnesses" claimants from Portugal. This seems to be part of a move (coordinated to some extent by international staff discusssion) to shut out Third World refugee masses from our neat, tidy and prosperous "First World". Hungry people from countries impoverished by our corporations who use their land to grow cheap crops for us, or from countries ruled by governments more friendly to us than to their own people, sometimes use the facilities of modern travel to arrive in Canada. Our immigration authorities frequently try to keep them out. The legal battles are many and the moral issue is grave. I believe the Minister ought to review our whole visa policy and invite public discussion of it.

On March 14, 1984, Canada imposed visa requirements on Guatemalans. This was the same year Canada co-sponsored a UN Resolution ting time requirements under which the claims may be heard, and suggests a case-by-case clearance of the backlog rather than instituting a comprehensive and collective policy.

To criticize the Conservative government's approach without an optional programme would be unfair. I found the following liberal principles as the alternative to the government's stand.

Internationally, Canada has established itself as a country of human compassion and understanding, whose borders were open and accessible to all those individuals who needed and sought opportunity and hope for a better future for themselves and their children.

The Conservatives' proposed vision to address the realities of those seeking refuge, and particularly the new phenomena whereby refugees are arriving at our doorstep as opposed to immigration officials selecting them from refugee camps throughout the world, is

\section{Forum}

condemning Guatemala for grave human rights violations. We had many incontrovertible reports that the armed forces had massacred Indians and other campesinos and that the death squads "disappeared", tortured and killed trade union activists, outspoken intellectuals and church leaders. Mexico was uncertain as safe haven. The US refused safe haven, (not surprisingly, since it was the ally, if not the author, of the reign of military terror). Canada gives safe haven -- for which we are very thankful -- but restricts access to it. Why?

Our government's excuse is that Canada instituted a special programme for Guatemala, by which our Embassy has helped many hundreds of Guatemalans to escape death threats and to enter Canada on Minister's Permits. That is true, but does not justify shutting Canada's door to other genuine refugees who escape the death squads on their own. The government raised the fear of bogus refugees flooding into the country, but their own statistics belie that argument.

From January 1981 till March 1984, Canada accepted $67 \%$ of claimants from Guatemala -- 279 whose lives were saved, against 139 who failed to meet the strict Geneva definition but of whom many qualified for entry on

inadequate. All of the following principles must be respected:

1)

2)

Speedy reunification of refugee with his/her family after the granting of refugee status is essential to their well-being; also a lengthy separation has dangerous repercussions for family members who remain in the homeland country.

The afore-mentioned principles will serve to reestablish Canada's traditional leadership role in safeguarding the plight of refugees and their human rights.

humanitarian grounds. There was no flood of bogus applicants. Canada has done similarly with Chileans and Salvadoreans. From January 1981 to August 31, 1986, three hundred and six Chilean refugee claimants in Canada were accepted, and 296 were rejected. This acceptance rate is over $50 \%$, twice the general average. Two hundred and thirty-nine Salvadoreans were accepted, and 526 rejected .. which is still consistent with the general average.

Why has Canada tried to shut the door to Chileans, Salvadoreans and Guatemalans who came to Canada to claim refugee status? Does Canada restrict access to refugees as a policy? If so, who chose this policy? Not Parliament.The Minister? The bureaucrats? And why?

European countries are faced with a greater volume of inland refugee claimants arriving from countries nearer to them than any are to Canada. They are responding generally by restricting access. Is this becoming a policy of "Western" or "Northern" governments? And is it decided by elected representatives, by the international network of bureaucrats, or by others?

The military and industrial-commercial policies of the "Western" or "Northern" countries align us generally with the governments of many Third World refugee-producing countries. Is this our intention? If not, Canada ought to set a clear humane policy by removing the visa requirements from Guatemala,El Salvador and Chile. 